\title{
ORGANOGENESIS KALUS TANAMAN KRISAN (Chrysanthemum indicum L.) DENGAN PENGGUNAAN KINETIN DAN NAA (Naphthalene Acetic Acid)
}

\author{
ORGANOGENESIS OF CHRYSANTHEMUM (Chrysanthemum indicum L.) CALLUS USING \\ KINETIN AND NAA (Naphthalene Acetic Acid)
}

\begin{abstract}
Aliffia Restu Dinika ${ }^{1}$, Nurcahyo Widyodaru Saputro ${ }^{2}$, Kuswarini Sulandjari $^{3}$, Hayatul Rahmi ${ }^{4}$
Abstrak

Krisan (Chrysanthemum indicum L.) adalah salah satu jenis tanaman hias yang banyak diminati di Indonesia. Perbanyakan tanaman krisan bisa dilakukan dengan cara kultur jaringan. Tujuan penelitian ini adalah untuk mendapatkan konsentrasi kinetin dan NAA (Naphthalene Acetic Acid) yang memberikan pertumbuhan organogenesis pada kalus tanaman krisan (Chrysanthemum indicum L.). Media dasar yang digunakan adalah Murashige dan Skoog. Penelitian ini terdiri dari 16 perlakuan. Hasil penelitian menunjukkan terdapat pertumbuhan tunas yang berjumlah 3 tunas pada 3 perlakuan, serta pertumbuhan akar pada 1 perlakuan. Konsentrasi Kinetin dan NAA (Naphthalene Acetic Acid) yang berhasil memberikan pertumbuhan tunas adalah konsentrasi Kinetin $0 \mathrm{mg} / \mathrm{l}+\mathrm{NAA}$ $1 \mathrm{mg} / \mathrm{l}$ (perlakuan $\mathrm{K}_{1} \mathrm{~N}_{3}$ ), konsentrasi Kinetin $2 \mathrm{mg} / \mathrm{l}+\mathrm{NAA} 0,5 \mathrm{mg} / \mathrm{l}$ (perlakuan $\mathrm{K}_{2} \mathrm{~N}_{2}$ ), dan konsentrasi Kinetin $3 \mathrm{mg} / \mathrm{l}+\mathrm{NAA} 0,5 \mathrm{mg} / \mathrm{l}$ (perlakuan $\mathrm{K}_{4} \mathrm{~N}_{2}$ ). Untuk konsentrasi Kinetin dan NAA (Naphthalene Acetic Acid) yang berhasil memberikan pertumbuhan akar adalah konsentrasi Kinetin 3 $\mathrm{mg} / 1+\mathrm{NAA} 0,5 \mathrm{mg} / \mathrm{l}$ (perlakuan $\mathrm{K}_{4} \mathrm{~N}_{2}$ ).
\end{abstract}

Kata kunci : Organogenesis, Kinetin, NAA, Kalus

\section{Abstract}

Chrysanthemum (Chrysanthemum indicum L.) is a type of ornamental plant that is in great demand in Indonesia. Chrysanthemum plant propagation can be done by means of tissue culture. The purpose of this study was to obtain the concentration of kinetin and NAA (Naphthalene Acetic Acid) which gave the growth of organogenesis in the callus of chrysanthemum plants. The basic media used are Murashige and Skoog. This study consisted of 16 treatments. The results showed that there was shoot growth, amounting to 3 shoots in 3 treatments, as well as root growth in 1 treatment. The concentrations of Kinetin and NAA (Naphthalene Acetic Acid) that succeeded in providing shoot growth were Kinetin concentration $0 \mathrm{mg} / 1+\mathrm{NAA} 1 \mathrm{mg} / 1\left(\mathrm{~K}_{1} \mathrm{~N}_{3}\right.$ treatment), Kinetin concentration 2 $\mathrm{mg} / 1+\mathrm{NAA} 0.5 \mathrm{mg} / 1\left(\mathrm{~K}_{2} \mathrm{~N}_{2}\right.$ treatment $)$, and Kinetin concentration $3 \mathrm{mg} / 1+\mathrm{NAA} 0.5 \mathrm{mg} / 1$ $\left(\mathrm{K}_{4} \mathrm{~N}_{2}\right.$ treatment). For the concentration of Kinetin and NAA (Naphthalene Acetic Acid) that succeeded in providing root growth was the concentration of Kinetin $3 \mathrm{mg} / 1+\mathrm{NAA} 0.5 \mathrm{mg} / 1\left(\mathrm{~K}_{4} \mathrm{~N}_{2}\right.$ treatment).

Keyword : Organogenesis, kinetin, NAA, Callus

\section{PENDAHULUAN}

Krisan (Chrysanthemum indicum L.) merupakan salah satu jenis tanaman hias berupa bunga potong yang sangat populer di Indonesia (Wediyanto, 2007). Saat ini krisan termasuk bunga potong trend setter di Indonesia karena memiliki keunggulan: kaya akan warna, ukuran dan bentuk, tahan lama, serta mempunyai bau yang harum (Purwanto dan Martini, 2013).
Menurut Pusdatin (2015) dan Basis Data Statistik Pertanian (2018), perkembangan ketersediaan krisan di Indonesia selama periode 2007-2012 meningkat, sedikit mengalami penurunan pada tahun 2013 sebesar 2,59\%. Pada tahun 2014 kembali meningkat sebesar $10,35 \%$, selanjutnya tahun 2015 sampai dengan 2016 terus mengalami penurunan. Pertumbuhan konsumsi krisan per 
tahun pada periode tahun 2007-2016

berfluktuasi dengan rata-rata $26,06 \%$ (Tabel 1) Tabel 1. Perkembangan ketersediaan dan konsumsi krisan di Indonesia Tahun 2007-2016

\begin{tabular}{ccccccc}
\hline $\begin{array}{c}\text { Tahun } \\
(\text { Year })\end{array}$ & $\begin{array}{c}\text { Tangkai } \\
\text { (Stalk) }\end{array}$ & Kg & $\begin{array}{c}\text { Vol. ekspor } \\
\text { (Exported } \\
\text { volume) Kg }\end{array}$ & $\begin{array}{c}\text { Vol. } \\
\text { impor(Imported } \\
\text { volume) Kg }\end{array}$ & $\begin{array}{c}\text { Konsumsi } \\
\text { (Consumption) } \\
\text { Kg }\end{array}$ & $\begin{array}{c}\text { Pertumbuhan } \\
\text { konsumsi } \\
\text { (Consumption } \\
\text { growth), \% }\end{array}$ \\
\hline 2007 & 66.979 .260 & 6.697 .926 & 39.059 & 177 & 6.659 .044 & \\
2008 & 101.777 .126 & 10.177 .713 & 60.501 & 1.010 & 10.118 .222 & 51,95 \\
2009 & 107.847 .072 & 10.784 .707 & 37.791 & 2.016 & 10.748 .932 & 6,23 \\
2010 & 185.232 .970 & 18.523 .297 & 63.063 & 3.024 & 18.463 .258 & 71,77 \\
2011 & 305.867 .882 & 30.586 .788 & 59.547 & 4.424 & 30.531 .665 & 65,36 \\
2012 & 397.651 .571 & 39.765 .157 & 79.102 & 8.000 & 39.694 .055 & 30,01 \\
2013 & 387.208 .754 & 38.720 .875 & 57.049 & 2.976 & 38.666 .802 & $-2,59$ \\
2014 & 427.248 .059 & 42.724 .806 & 56.227 & 240 & 42.668 .819 & 10,35 \\
2015 & 442.698 .194 & 44.269 .819 & 59.625 & 5.250 & 44.215 .444 & 3,62 \\
2016 & 433.100 .145 & 43.310 .015 & 60.648 & 6.975 & 43.256 .342 & $-2,17$ \\
\hline
\end{tabular}

Sumber: Outlook komoditi krisan (Pusdatin, 2015)

Para pengusaha atau petani krisan membeli benih tanaman krisan dari produsen luar negeri. Ini disebabkan permintaan konsumen yang terus meningkat sehingga pengusaha dan petani harus mengimbanginya (Lilik et al., 2014). Adapun kendala yang sering dihadapi dalam pengembangan dan budidaya krisan adalah sulitnya ketersediaan benih yang seragam, bermutu tinggi dan sehat dalam jumlah yang banyak dengan waktu yang relatif singkat (Syaifan, 2010).

Salah satu alternatif untuk mendapatkan tanaman krisan dalam jumlah banyak dan waktu singkat adalah dengan dilakukan perbanyakan secara in-vitro melalui teknik kultur jaringan (Syaifan, 2010). Perbanyakan tanaman krisan yang dilakukan dengan cara kultur jaringan diharapkan dapat menghasilkan kualitas bibit krisan yang unggul dan seragam, tahan terhadap penyakit, tingkat produksi tinggi serta waktu yang relatif lebih singkat jika dibandingkan dengan perbanyakan secara konvensional (Lubis, 2016).

Penggandaan biakan dalam kultur in vitro dapat dilakukan melalui jalur organogenesis (Purnamaningsih, 2003). Organogenesis adalah proses terbentuknya organ seperti pucuk dan akar (Gunawan, 1992). Terdapat dua cara terjadinya organogenesis yaitu secara langsung atau tidak langsung. Organogenesis langsung ditandai dengan eksplan yang ditanam langsung beregenerasi membentuk tunas dan daun setelah eksplan tersebut ditanam, sedangkan organogenesis tidak langsung ditandai dengan pembentukan organ-organ tanaman seperti tunas, daun, akar terjadi setelah eksplan beregenerasi menjadi kalus (Suminar et al., 2017). Kalus adalah poliferasi massa jaringan yang belum terdeferensiasi dan dapat terbentuk pada seluruh bagian permukaan yang terkena irisan eksplan (Lina et al., 2013). Pembentukan kalus sangat penting dalam proses regenerasi tanaman karena memungkinkannya dihasilkan tunas dari selsel baru, bukan berasal dari meristem yang sudah ada sebelumnya (Marthani et al., 2016). Menurut Lestari dan Yunita (2008), Kalus yang baru terbentuk berpeluang menghasilkan tunas lebih tinggi dibandingkan kalus yang telah disubkultur berkali-kali, karena kalus yang baru terbentuk kandungan poliamin atau senyawa yang berperan dalam sistem regenerasi masih tinggi.

Auksin dan sitokinin adalah zat pengatur tumbuh yang sering ditambahkan kedalam media tanam kultur jaringan karena mempengaruhi pertumbuhan dan organogenensis dalam kultur jaringan 
(Wahyudi et al., 2013). Kinetin merupakan zat pengatur tumbuh jenis sitokinin, berfungsi sebagai pengatur pembelahan sel dan morfogenesis. NAA merupakan zat pengatur tumbuh jenis auksin, berfungsi sebagai perangsang atau mendorong pengembangan sel (Lindung, 2014).

Kinetin berpengaruh nyata terhadap jumlah tunas krisan kulo, konsentrasi terbaik yang digunakan yaitu 3 ppm (Tilaar et al., 2015). Penggunaan Kinetin dan NAA dengan konsentrasi $3 \mathrm{mg} / \mathrm{L}$ kinetin $+2 \mathrm{mg} / \mathrm{L}$ NAA memberikan hasil terbaik terhadap jumlah tunas tanaman krisan (Royani dan Fatmawati, 2016). Penelitian ini akan membahas mengenai organogenesis pada kalus tanaman krisan. Tujuan penelitian ini adalah untuk mendapatkan konsentrasi kinetin dan NAA (Naphthalene Acetic Acid) yang memberikan pertumbuhan organogenesis pada kalus tanaman krisan (Chrysanthemum indicum L.).

Berikut merupakan 16 perlakuan konsentrasi kombinasi kinetin dan NAA :

1. $\mathrm{K}_{1} \mathrm{~N}_{1}=$ Kontrol

2. $\mathrm{K}_{1} \mathrm{~N}_{2}=$ Tanpa kinetin + NAA $0,5 \mathrm{mg} / \mathrm{L}$

3. $\mathrm{K}_{1} \mathrm{~N}_{3}=$ Tanpa kinetin + NAA $1 \mathrm{mg} / \mathrm{L}$

4. $\mathrm{K}_{1} \mathrm{~N}_{4}=$ Tanpa kinetin $+\mathrm{NAA} 1,5 \mathrm{mg} / \mathrm{L}$

5. $\mathrm{K}_{2} \mathrm{~N}_{1}=$ Kinetin $2 \mathrm{mg} / \mathrm{L}+$ Tanpa NAA

6. $\mathrm{K}_{2} \mathrm{~N}_{2}=$ Kinetin $2 \mathrm{mg} / \mathrm{L}+$ NAA $0,5 \mathrm{mg} / \mathrm{L}$

7. $\mathrm{K}_{2} \mathrm{~N}_{3}=$ Kinetin $2 \mathrm{mg} / \mathrm{L}+\mathrm{NAA} 1 \mathrm{mg} / \mathrm{L}$

Langkah penanaman pada penelitian ini yaitu, memotong kalus tanaman krisan yang didapat dari perbanyakan in vitro sebelumnya, lalu kalus dipotong menjadi 2-3 bagian, kalus yang sudah dipotong dipindahkan ke botol media yang baru, dalam 1 botol diisi 1 kalus. Selanjutnya botol yang sudah berisi kalus ditutup menggunakan alumunium foil lalu diikat dengan karet kemudian dilapisi menggunakan plastik wrap. Tahap selanjutnya, botol-botol kultur disimpan di rak kultur.

Pada penelitian ini dilakukan pengamatan selama sepuluh minggu.

\section{BAHAN DAN METODE PENELITIAN}

Penelitian ini dilaksanakan di Laboratorium Bioteknologi Tanaman, Program Studi Agroteknologi, Fakultas Pertanian, Universitas Singaperbangsa Karawang. Penelitian dilaksanakan mulai pada bulan Juni sampai dengan bulan September 2020. Bahan yang digunakan dalam penelitian ini terdiri dari kalus tanaman krisan yang diperoleh dari perbanyakan in vitro sebelumnya, media Murashige dan Skoog (MS), ZPT Kinetin dan NAA, agar-agar, gula pasir, alkohol $70 \%$, aquadest. Alat yang digunakan dalam penelitian ini adalah Laminar Air Flow Cabinet (LAFC), autoclave, magnetic stirer, kulkas, timbangan analitik, $\mathrm{pH}$ meter dan alat-alat tanam.

Pada penelitian ini terdapat 16 perlakuan yang diulang sebanyak 5 kali, sehingga terdapat 80 unit penelitian. Data hasil penelitian dianalisis secara deskriptif. Dalam 1 botol kultur diletakan 1 irisan kecil kalus.

8. $\mathrm{K}_{2} \mathrm{~N}_{4}=$ Kinetin $2 \mathrm{mg} / \mathrm{L}+\mathrm{NAA} 1,5 \mathrm{mg} / \mathrm{L}$

9. $\mathrm{K}_{3} \mathrm{~N}_{1}=$ Kinetin $2,5 \mathrm{mg} / \mathrm{L}+$ Tanpa NAA

10. $\mathrm{K}_{3} \mathrm{~N}_{2}=$ Kinetin $2,5 \mathrm{mg} / \mathrm{L}+\mathrm{NAA} 0,5 \mathrm{mg} / \mathrm{L}$

11. $\mathrm{K}_{3} \mathrm{~N}_{3}=$ Kinetin $2,5 \mathrm{mg} / \mathrm{L}+\mathrm{NAA} 1 \mathrm{mg} / \mathrm{L}$

12. $\mathrm{K}_{3} \mathrm{~N}_{4}=$ Kinetin $2,5 \mathrm{mg} / \mathrm{L}+\mathrm{NAA} 1,5 \mathrm{mg} / \mathrm{L}$

13. $\mathrm{K}_{4} \mathrm{~N}_{1}=$ Kinetin $3 \mathrm{mg} / \mathrm{L}+$ Tanpa NAA

14. $\mathrm{K}_{4} \mathrm{~N}_{2}=$ Kinetin $3 \mathrm{mg} / \mathrm{L}+\mathrm{NAA} 0,5 \mathrm{mg} / \mathrm{L}$

15. $\mathrm{K}_{4} \mathrm{~N}_{3}=$ Kinetin $3 \mathrm{mg} / \mathrm{L}+\mathrm{NAA} 1 \mathrm{mg} / \mathrm{L}$

16. $\mathrm{K}_{4} \mathrm{~N}_{4}=$ Kinetin $3 \mathrm{mg} / \mathrm{L}+\mathrm{NAA} 1,5 \mathrm{mg} / \mathrm{L}$

Parameter yang diamati adalah waktu muncul tunas, persentase tumbuh tunas, respon lain berupa munculnya akar dan perubahan warna kalus.

\section{HASIL DAN PEMBAHASAN}

Waktu Muncul Tunas

Hasil dari penelitian ini terdapat 3 tunas pada 3 perlakuan yang berbeda yaitu $\mathrm{K}_{1} \mathrm{~N}_{3}$ (Tanpa kinetin + NAA $1 \mathrm{mg} / \mathrm{L}$ ), $\mathrm{K}_{2} \mathrm{~N}_{2}$ (Kinetin $2 \mathrm{mg} / \mathrm{L}+$ NAA $0,5 \mathrm{mg} / \mathrm{L}$ ) dan $\mathrm{K}_{4} \mathrm{~N}_{2}$ (Kinetin $3 \mathrm{mg} / \mathrm{L}+$ NAA $0,5 \mathrm{mg} / \mathrm{L}$ ). Tunas hasil organogenesis kalus krisan disajikan pada Gambar 1. 


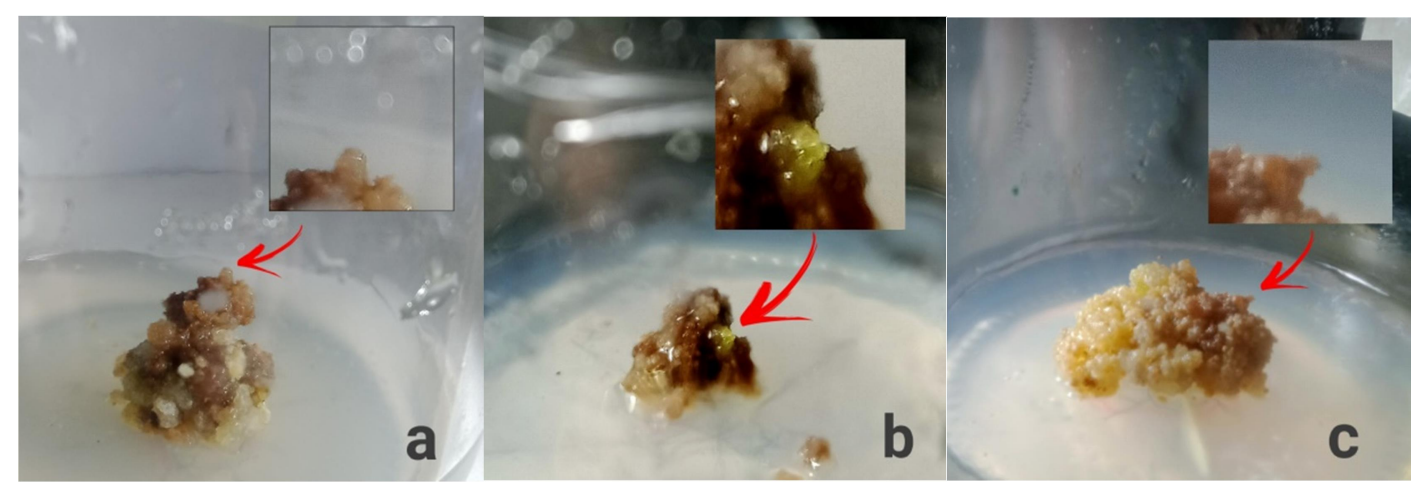

Gambar 1. Tunas pada 3 perlakuan, a.Perlakuan K1N3 (NAA $1 \mathrm{mg} / \mathrm{L}$ ), b.Perlakuan K2N2 (Kinetin 2 mg/l+NAA 0,5 mg/L), c.Perlakuan K4N2 (Kinetin $3 \mathrm{mg} / \mathrm{l}+\mathrm{NAA} 0,5 \mathrm{mg} / \mathrm{L}$ )

Berdasarkan data hasil penelitian diketahui bahwa pemberian berbagai konsentrasi zat pengatur tumbuh kinetin dan NAA (Naphtalene Acetic Acid) memberikan pengaruh yang berbeda pada waktu muncul tunas. Data munculnya tunas pada setiap perlakuan tersaji pada Tabel 2.

Tabel 2. Waktu muncul tunas pada setiap perlakuan

\begin{tabular}{|c|c|c|c|c|}
\hline \multirow{2}{*}{ Kinetin (K) } & \multicolumn{4}{|c|}{ NAA (N) } \\
\hline & $0 \mathrm{mg} / \mathrm{l}\left(\mathrm{N}_{1}\right)$ & $0,5 \mathrm{mg} / \mathrm{l}\left(\mathrm{N}_{2}\right)$ & $1,0 \mathrm{mg} / \mathbf{l}\left(\mathrm{N}_{3}\right)$ & $1,5 \mathrm{mg} / \mathrm{l}\left(\mathrm{N}_{4}\right)$ \\
\hline $0 \mathrm{mg} / \mathrm{l}\left(\mathrm{K}_{1}\right)$ & - & - & $9 \mathrm{MST}$ & - \\
\hline $2 \mathrm{mg} / \mathrm{l}\left(\mathrm{K}_{2}\right)$ & . & $10 \mathrm{MST}$ & - & - \\
\hline $2,5 \mathrm{mg} / \mathrm{l}\left(\mathrm{K}_{3}\right)$ & - & - & - & - \\
\hline $3 \mathrm{mg} / \mathrm{l}\left(\mathrm{K}_{4}\right)$ & - & 9 MST & - & - \\
\hline
\end{tabular}

Keterangan: (-) tidak tumbuh tunas

Tabel 2 menjelaskan bahwa tunas pertama kali muncul pada 9 MST, yaitu pada perlakuan $\mathrm{K}_{1} \mathrm{~N}_{3}$ (Tanpa kinetin + NAA 1 $\mathrm{mg} / \mathrm{L}$ ) dan $\mathrm{K}_{4} \mathrm{~N}_{2}$ (Kinetin $3 \mathrm{mg} / \mathrm{L}+$ NAA 0,5 $\mathrm{mg} / \mathrm{L}$ ). Selanjutnya, tunas kembali muncul pada 10 MST yaitu pada perlakuan $\mathrm{K}_{2} \mathrm{~N}_{2}$ (Kinetin $2 \mathrm{mg} / \mathrm{L}+$ NAA 0,5 mg/L). Dari ketiga perlakuan tersebut hanya $\mathrm{K}_{1} \mathrm{~N}_{3}$ (Tanpa kinetin + NAA $1 \mathrm{mg} / \mathrm{L}$ ) yang menggunakan perlakuan NAA tanpa kombinasi kinetin, walaupun hanya menggunakan NAA tetapi tetap mampu menginduksi pertumbuhan tunas. Hal ini sejalan dengan penelitian Edri et al (2013), bahwa pemberian NAA secara tunggal pada multiplikasi embrio aren secara in vitro memberikan pengaruh pada parameter umur muncul tunas. Pemberian auksin pada media kultur dapat meningkatkan proses-proses fisiologis pada sel-sel tanaman yang dikultur, seperti turut membantu dalam memacu pembelahan sel-sel pada jaringan serta berbagai proses organogenesis, diantaranya dalam pembentukan dan pertumbuhan tunas (Ali et al., 2007). Pada perlakuan $\mathrm{K}_{2} \mathrm{~N}_{2}$ (Kinetin $2 \mathrm{mg} / \mathrm{L}+$ NAA $0,5 \mathrm{mg} / \mathrm{L}$ ) dan $\mathrm{K}_{4} \mathrm{~N}_{2}$
(Kinetin $3 \mathrm{mg} / \mathrm{L}+$ NAA $0,5 \mathrm{mg} / \mathrm{L}$ ), zat pengatur tumbuh kinetin lebih tinggi konsentrasinya dibandingkan NAA. Hal ini sesuai dengan pernyataan Skoog dan Miller (1997), bahwa jika sitokinin tinggi dan auksin rendah maka akan terjadi pembentukan tunas.

Pada penelitian ini pertumbuhan tunas terjadi pada waktu yang relatif cukup lama, Hal ini diduga karena konsentrasi dan level sitokinin endogen di dalam kalus krisan rendah, sehingga pemberian sitokinin eksogen pada media masih belum mampu meningkatkan kecepatan waktu kemunculan tunas. Lamanya partumbuhan tunas juga dipengaruhi oleh kerja hormon sitokinin dan auksin yang saling berkolerasi. Efektivitas zat pengatur tumbuh auksin maupun sitokinin eksogen bergantung pada konsentrasi hormon endogen dalam jaringan tanaman (Indah \& Ermavitalini, 2013).

\section{Persentase Tumbuhnya Tunas}

Penentuan persentase tumbuhnya tunas tanaman krisan diperoleh dengan cara menghitung total ulangan yang tumbuh tunas dibagi dengan banyaknya ulangan lalu dikali 
100\%. Data pengamatan persentase tumbuh tunas disajikan pada Tabel 3.
Tabel 3. Persentase tumbuhnya tunas pada tiap perlakuan

\begin{tabular}{|c|c|c|c|c|}
\hline \multirow{2}{*}{ Kinetin } & \multicolumn{4}{|c|}{ NAA } \\
\hline & $0 \mathrm{mg} / \mathrm{l}\left(\mathrm{N}_{1}\right)$ & $0,5 \mathrm{mg} / \mathrm{l}\left(\mathrm{N}_{2}\right)$ & $1 \mathrm{mg} / \mathrm{l}\left(\mathrm{N}_{3}\right)$ & $1,5 \mathrm{mg} / \mathrm{l}\left(\mathrm{N}_{4}\right)$ \\
\hline $0 \mathrm{mg} / \mathrm{l}\left(\mathrm{K}_{1}\right)$ & $0 \%$ & $0 \%$ & $20 \%$ & $0 \%$ \\
\hline $2 \mathrm{mg} / \mathrm{l}\left(\mathrm{K}_{2}\right)$ & $0 \%$ & $20 \%$ & $0 \%$ & $0 \%$ \\
\hline $2,5 \mathrm{mg} / \mathrm{l}\left(\mathrm{K}_{3}\right)$ & $0 \%$ & $0 \%$ & $0 \%$ & $0 \%$ \\
\hline $3 \mathrm{mg} / \mathrm{l}\left(\mathrm{K}_{4}\right)$ & $0 \%$ & $20 \%$ & $0 \%$ & $0 \%$ \\
\hline
\end{tabular}

Pada Tabel 3 terdapat 3 perlakuan yang berhasil menumbuhkan tunas, yaitu perlakuan $\mathrm{K}_{1} \mathrm{~N}_{3}$ (Tanpa kinetin + NAA 1 $\mathrm{mg} / \mathrm{l}$ ), $\mathrm{K}_{2} \mathrm{~N}_{2}$ (Kinetin $2 \mathrm{mg} / \mathrm{L}+$ NAA 0,5 $\mathrm{mg} / \mathrm{L}$ ) dan $\mathrm{K}_{4} \mathrm{~N}_{2}$ (Kinetin $3 \mathrm{mg} / \mathrm{L}+$ NAA 0,5 $\mathrm{mg} / \mathrm{L}$ ). Pada perlakuan $\mathrm{K}_{1} \mathrm{~N}_{3}$ yang hanya menggunakan zat pengatur tumbuh NAA konsentrasi $1 \mathrm{mg} / \mathrm{L}$ tanpa kinetin mampu menginduksi pertumbuhan tunas, Hal ini diduga karena pemberian auksin pada media kultur dapat meningkatkan proses-proses fisiologis pada sel-sel tanaman yang dikultur, seperti turut membantu dalam memacu pembelahan sel-sel pada jaringan serta berbagai proses organogenesis, diantaranya pada pembentukan dan pertumbuhan tunas (Ali et al., 2007). Zat pengatur tumbuh sitokinin endogen dalam kalus krisan perlakuan $\mathrm{K}_{1} \mathrm{~N}_{3}$ (Tanpa kinetin + NAA 1 $\mathrm{mg} / \mathrm{L}$ ) mampu menyediakan dan mencukupi, sehingga walaupun tidak ditambahkan sitokinin eksogen tetap mampu menginduksi pertumbuhan tunas.

Pada perlakuan $\mathrm{K}_{2} \mathrm{~N}_{2}$ (Kinetin $2 \mathrm{mg} / \mathrm{L}$ + NAA 0,5 $\mathrm{mg} / \mathrm{L}$ ) dan perlakuan $\mathrm{K}_{4} \mathrm{~N}_{2}$ (Kinetin $3 \mathrm{mg} / \mathrm{L}+\mathrm{NAA} 0,5 \mathrm{mg} / \mathrm{L}$ ) kedua perlakuan ini menggunakan zat pengatur tumbuh sitokinin yang konsentrasinya lebih tinggi dibandingkan konsentrasi zat pengatur tumbuh auksin. Wattimena (1988), mengemukakan bahwa pemberian auksin yang rendah dan sitokinin yang lebih tinggi cenderung mendorong pembentukan tunas adventif dan juga poliferasi tunas aksilar. Hal ini sesuai dengan pernyataan Prematilake \& Mendis (1999), bahwa auksin turut dibutuhkan untuk mendorong pembentukan tunas, namun umumnya dibutuhkan dalam jumlah atau konsentrasi yang rendah.

\section{Respon Lain}

Respon lain yang terjadi pada kalus adalah munculnya akar pada perlakuan $\mathrm{K}_{4} \mathrm{~N}_{2}$ (Kinetin $3 \mathrm{mg} / \mathrm{L}+$ NAA $0,5 \mathrm{mg} / \mathrm{L}$ ). Akar mulai muncul saat pengamatan telah selesai, tepatnya saat 17 mst. Menurut Nella et al (2017), lamanya waktu muncul akar bisa disebabkan oleh beberapa faktor yang menghambat proses pertumbuhan dan perkembangan akar eksplan.

Gambar 2. Akar pada perlakuan $\mathrm{K}_{4} \mathrm{~N}_{2}$ (Kinetin $3 \mathrm{mg} / \mathrm{L}+\mathrm{NAA} 0,5 \mathrm{mg} / \mathrm{L})$

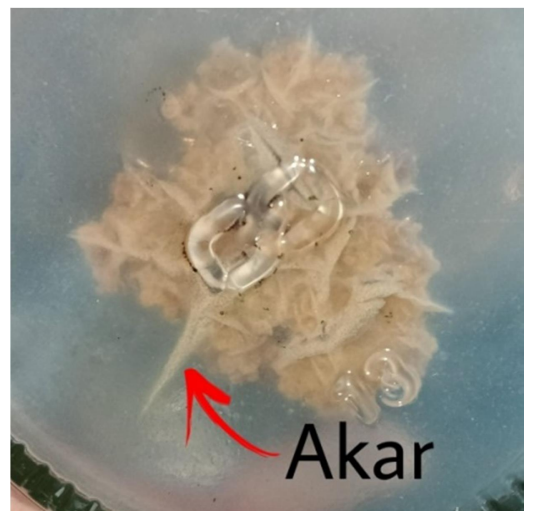

Gambar 2. Akar pada perlakuan K4N2 (Kinetin $3 \mathrm{mg} / \mathrm{l}+\mathrm{NAA}$ 0,5 mg/L) 
Munculnya akar ditandai dengan adanya garis panjang berwarna putih yang berada di bagian bawah kalus yang terlihat pada bagian bawah botol (Gambar 4). Akar terdapat pada perlakuan $\mathrm{K}_{4} \mathrm{~N}_{2}$ (Kinetin $3 \mathrm{mg} / \mathrm{L}$ + NAA 0,5 $\mathrm{mg} / \mathrm{L}$ ), perlakuan $\mathrm{K}_{4} \mathrm{~N}_{2}$ ini merupakan perlakuan yang konsentrasi zat pengatur tumbuh sitokinin lebih tinggi dibandingkan auksin, Hal ini sejalan dengan hasil penelitian Mahadi, et al. (2013) bahwa NAA dan kinetin berpengaruh nyata terhadap jumlah akar eksplan buah Naga (Hylocereus costaricensis). Rataan jumlah akar eksplan buah naga tertinggi pada perlakuan $0,4 \mathrm{ppm}$ NAA dan 4 ppm kinetin, dimana dalam penelitian Mahadi, et al. (2013) ini konsentrasi sitokinin levelnya 10x lebih tinggi dibandingkan konsentrasi auksin. Menurut Agustina (2002) dalam Nurhanis et al. (2019), munculnya akar disebabkan oleh masih tingginya auksin yang terdapat dalam eksplan (endogen) sehingga walaupun ditambahkan auksin secara eksogen dengan konsentrasi rendah akan dapat membentuk akar.

\section{Perubahan Warna Kalus}

Warna kalus menggambarkan penampilan visual sel-sel kalus sehingga dapat diketahui tingkat keaktifan pembelahan selselnya (Rasud dan Bustaman, 2020). Kalus yang didapat dari perbanyakan in vitro sebelumnya dominan berwarna kuning kecoklatan. Data perubahan warna kalus disajikan pada Tabel 4.

Tabel 4. Perubahan warna kalus

\begin{tabular}{|c|c|c|}
\hline \multirow{2}{*}{ Perlakuan } & \multicolumn{2}{|c|}{ Warna Kalus } \\
\hline & Awal & Akhir \\
\hline $\mathrm{K}_{1} \mathrm{~N}_{1}$ (Kontrol) & Kuning kecoklatan & Putih kecoklatan \\
\hline $\mathrm{K}_{1} \mathrm{~N}_{2}$ (Tanpa kinetin + NAA $\left.0,5 \mathrm{mg} / \mathrm{L}\right)$ & Kuning kecoklatan & Putih kecoklatan \\
\hline $\mathrm{K}_{1} \mathrm{~N}_{3}$ (Tanpa kinetin + NAA $\left.1 \mathrm{mg} / \mathrm{L}\right)$ & Kuning kecoklatan & Kuning kecoklatan \\
\hline $\mathrm{K}_{1} \mathrm{~N}_{4}($ Tanpa kinetin + NAA $1,5 \mathrm{mg} / \mathrm{L})$ & Kuning kecoklatan & Putih kecoklatan \\
\hline $\mathrm{K}_{2} \mathrm{~N}_{1}$ (Kinetin $2 \mathrm{mg} / \mathrm{L}+$ Tanpa NAA) & Kuning kecoklatan & Coklat \\
\hline $\mathrm{K}_{2} \mathrm{~N}_{2}$ (Kinetin $2 \mathrm{mg} / \mathrm{L}+$ NAA $0,5 \mathrm{mg} / \mathrm{L}$ & Kuning kecoklatan & Coklat \\
\hline $\mathrm{K}_{2} \mathrm{~N}_{3}($ Kinetin $2 \mathrm{mg} / \mathrm{L}+\mathrm{NAA} 1 \mathrm{mg} / \mathrm{L})$ & Kuning kecoklatan & Putih kecoklatan \\
\hline $\mathrm{K}_{2} \mathrm{~N}_{4}($ Kinetin $2 \mathrm{mg} / \mathrm{L}+\mathrm{NAA} 1,5 \mathrm{mg} / \mathrm{L})$ & Kuning kecoklatan & Putih kecoklatan \\
\hline $\mathrm{K}_{3} \mathrm{~N}_{1}$ (Kinetin $2,5 \mathrm{mg} / \mathrm{L}+$ Tanpa NAA) & Kuning kecoklatan & Coklat \\
\hline $\mathrm{K}_{3} \mathrm{~N}_{2}($ Kinetin $2,5 \mathrm{mg} / \mathrm{L}+\mathrm{NAA} 0,5 \mathrm{mg} / \mathrm{L})$ & Kuning kecoklatan & Putih kecoklatan \\
\hline $\mathrm{K}_{3} \mathrm{~N}_{3}($ Kinetin $2,5 \mathrm{mg} / \mathrm{L}+\mathrm{NAA} 1 \mathrm{mg} / \mathrm{L})$ & Kuning kecoklatan & Putih kecoklatan \\
\hline $\mathrm{K}_{3} \mathrm{~N}_{4}($ Kinetin $2,5 \mathrm{mg} / \mathrm{L}+\mathrm{NAA} 1,5 \mathrm{mg} / \mathrm{L})$ & Kuning kecoklatan & Coklat \\
\hline $\mathrm{K}_{4} \mathrm{~N}_{1}$ (Kinetin $3 \mathrm{mg} / \mathrm{L}+$ Tanpa NAA) & Kuning kecoklatan & Coklat \\
\hline $\mathrm{K}_{4} \mathrm{~N}_{2}($ Kinetin $3 \mathrm{mg} / \mathrm{L}+\mathrm{NAA} 0,5 \mathrm{mg} / \mathrm{L})$ & Kuning kecoklatan & Kuning kecoklatan \\
\hline $\mathrm{K}_{4} \mathrm{~N}_{3}($ Kinetin $3 \mathrm{mg} / \mathrm{L}+\mathrm{NAA} 1 \mathrm{mg} / \mathrm{L})$ & Kuning kecoklatan & Coklat \\
\hline $\mathrm{K}_{4} \mathrm{~N}_{4}($ Kinetin $3 \mathrm{mg} / \mathrm{L}+\mathrm{NAA} 1,5 \mathrm{mg} / \mathrm{L})$ & Kuning kecoklatan & Coklat \\
\hline
\end{tabular}

Berdasarkan Tabel 4, kalus yang sebelumnya berwarna kuning kecoklatan setelah dipindahkan ke media MS dengan penambahan zat pengatur tumbuh kinetin dan NAA (Naphtalene Acetic Acid) berbagai konsentrasi menghasilkan perubahan warna kalus yang bervariasi. Perbedaan warna kalus dapat disebabkan beberapa hal diantaranya yaitu pigmentasi, intensitas cahaya dan sumber eksplan dari bagian tanaman yang berbeda (Hendaryono \& Wijayani, 1994). Pada beberapa perlakuan, kalus yang awalnya berwarna kuning kecoklatan mengalami perubahan warna menjadi coklat. Sedangkan kalus yang berwarna putih merupakan kalus baru yang baru tumbuh. Kalus yang berwarna putih merupakan sel embrionik yang belum mengandung kloroplas, tetapi memiliki kandungan butir pati yang tinggi (Ariati et al., 2012). Kalus yang berwarna putih merupakan massa sel yang sedang aktif membelah (Rasud dan Bustaman, 2020). Kalus yang berwarna kekuningan menunjukkan bahwa kalus tersebut masih aktif berdiferensiasi 
(Purnamaningsih \& Ashrina, 2011). Sedangkan, kalus yang berwarna coklat kemungkinan besar pertumbuhan dan perkembangan kalus tersebut telah memasuki fase stasioner (penuaan) sehingga menyebabkan produksi metabolit sekunder menurun (Purnamaningsih dan Ashrina, 2011).

\section{KESIMPULAN}

Pemberian beberapa kombinasi ZPT kinetin dan NAA berhasil menumbuhkan tunas pada 3 perlakuan serta akar pada 1 perlakuan. Konsentrasi ZPT kinetin dan NAA yang berhasil tumbuh tunas yaitu konsentrasi tanpa kinetin + NAA $1 \mathrm{mg} / \mathrm{L}$ (perlakuan $\mathrm{K}_{1} \mathrm{~N}_{3}$ ), konsentrasi kinetin $2 \mathrm{mg} / \mathrm{L}+$ NAA $0,5 \mathrm{mg} / \mathrm{L}$ (perlakuan $\mathrm{K}_{2} \mathrm{~N}_{2}$ ), dan konsentrasi kinetin 3 $\mathrm{mg} / \mathrm{L}+\mathrm{NAA} 0,5 \mathrm{mg} / \mathrm{L}$ (perlakuan $\mathrm{K}_{4} \mathrm{~N}_{2}$ ). Konsentrasi ZPT kinetin dan NAA yang berhasil menumbuhkan akar adalah konsentrasi kinetin $3 \mathrm{mg} / \mathrm{L}+$ NAA $0,5 \mathrm{mg} / \mathrm{L}$ (perlakuan $\mathrm{K}_{4} \mathrm{~N}_{2}$ ).

\section{DAFTAR PUSTAKA}

Agustina L. 2002. Nutrisi Tanaman. Rineka Cipta, Jakarta.

Ali, G., F. Hadi, Z. Ali, M. Tariq, and M. A. Khan, 2007. Callus Induction and in Vitro Complete Plant Regeneration of Different Cultivars of Tobacco (Nicotiana tabacum L.) on Media of Different Hormonal Concentrations. Journal Biotechnology, 6(4): 561-566.

Ariati S, Niken, Muslimin, Waeniati, Suwastika IN. 2012. Induksi Kalus Kakao (Theobroma cacao L.) pada Media MS dengan Penambahan 2,4-D, BAP dan Air Kelapa. Jurnal Natural Science. 1(1): 74-78.

Basis Data Statistik Pertanian 2018. Diakses: Http://database.pertanian.go.id/eksim2 012asp/neraca.asp. [1 Maret 2021]

Edri W, Ernita, Fathurrahman. 2013. Uji Konsentrasi Kinetin dan NAA Terhadap Multiplikasi Embrio Aren (Arenga pinnata (W) Merr) Secara In Vitro. Jurnal Dinamika Pertanian, XXVIII.

Gunawan, L.W. 1992. Teknik Kultur Jaringan Tumbuhan. Laboratorium Kultur Jaringan Tumbuhan PAU Bioteknologi. Institut Pertanian Bogor. Bogor.
Hayati, N.Q., Nurmalinda., B. Marwoto. 2018. Inovasi Teknologi Tanaman Krisan yang Dibutuhkan Pelaku Usaha. J. Hort. 28(1): 147-162

Hendaryono, D.P.S. \& A. Wijayani. 1994. Teknik Kultur Jaringan. Kanisius, Yogyakarta.

Indah, P. N dan Ermavitalini, D. 2013. Induksi Kalus Daun Nyamplung (Calophyllum inophyllum L.) Pada Beberapa Kombinasi Konsentrasi 6-BAP dan 2,4-D. Jurnal Sains dan Sn Pomits. 2 (1): 2337-3520.

Lestari, E. G dan Yunita, R. 2008. Induksi Kalus dan Regenerasi Tunas Padi Varietas Fatmawati. Bul.Agron. 36(2): 106-110.

Lilik, Ninuk dan Eko. 2014. Respon Dua Kultivar Tanaman Krisan (Chrysanthemum morifolium) Pada Berbagai Lama Penambahan Cahaya Buatan. Jurnal Produksi Tanaman. 2 (1).

Lina, F. dan Wahyono, R. 2013. Pengaruh 6benzylamino purine (BAP) dan 6furfuryl amino purine (Kinetin) pada media MS terhadap Pertumbuhan Eksplan Ujung Apikal Tanaman Jati secara In Vitro. LenteraBio, 2(1): 167178.

Lindung. 2014. Teknologi Aplikasi Zat Pengatur Tumbuh. Diakses: http://www.bppjambi.info/newspopup. asp [18 April 2020]

Lubis, Yanti. 2016. Regenerasi In Vitro Tanaman Krisan Melalui Tunas Aksilar Sebagai Respon Terhadap Media Dasar dan Benzyl Adenin Serta Aklimatisasi Planlet. Skripsi. Fakultas Pertanian. Universitas Lampung, Lampung.

Mahadi I, Syafi'I W, dan Sari Y. 2013. Induksi Kalus Jeruk Kasturi (Citrus microcarpa) Menggunakan Hormon 2,4-D dan BAP dengan Metode In Vitro. Jurnal Ilmu Pertanian. 21 (2) : 84-89.

Marthani, Q., Anggraito, Y., Rahayu, E. 2016. Kalogenesis Eksplan Setengah Biji Koro Benguk (Mucuna pruriens L.) Secara In Vitro Menggunakan BAP dan NAA. Jurnal Unnes. 5(1). 
Nella, A, Luthfi, Lollie A. 2017. Pengaruh Zat Pengatur Tumbuh terhadap Induksi Akar (Rhizogenesis) pada Tanaman Bangun-Bangun (Plectranthus amboinicus (Lour.) Spreng) secara In Vitro. Jurnal Agroekoteknologi FP USU. 5 (3).

Nurhanis S, Reine, dan Rosa. 2019. Korelasi Konsentrasi IAA dan BAP Terhadap Pertumbuhan Kultur Jaringan Sengon (Paraserianthes falcataria). Jurnal Hutan Lestari. 7 (2): 857-867.

Prematilake, D.P. and M.H. Mendis, 1999. Microtubers of Potato (Solanum tuberosum): In Vitro Conservation and Tissue Culture. Journal Natn., 27 (1): $17-28$.

Purnamaningsih, R. 2003. Regenerasi Tanaman Melalui Embriogenesis Somatik dan Beberapa Gen yang Mengendalikannya. Jurnal Agro Biogen. 5 (2): 51-58.

Purnamaningsih, R dan Ashrina, M. 2011 Pengaruh BAP dan NAA terhadap Induksi Kalus dan Kandungan Artemisin dari Artemisia annua L. Berita Biologi 10(4).

Purwanto A.W, Tri Martini. 2013. Krisan Bunga Seribu Warna. Kanisius, Yogyakarta.

Pusdatin. 2015, Outlook komoditi krisan, Kementerian Pertanian, Jakarta, pp. 14-15.

Rasud, Y,. dan Bustaman. 2020. Induksi Kalus secara In Vitro dari Daun Cengkeh (Syizigium aromaticum L.) dalam Media dengan Berbagai Konsentrasi Auksin. Jurnal Ilmu Pertanian Indonesia. 25 (1): 67-72.
Royani I, Fatmawati A. 2016. Pengaruh Konsentrasi NAA dan Kinetin Terhadap Pertumbuhan Tanaman Krisan Secara In Vitro. Jurnal Ilmiah Biologi "Bioscientist". 4 (2).

Skoog, F. dan Miller. 1997. Chemical Regulation of Growth and Organ Formation in Plant Tissue Cultured in Vitro. Journal Biotechnology. 11 (2): 118-131.

Suminar, E., Sumadi, Mubarok, S., Sunarto, T., Rini, N. 2017. Percepatan Penyediaan Benih Sumber Kedelai Unggul Secara In Vitro. Jurnal Agrikultura. 28 (3): 126-135.

Syaifan, U. 2010. Pengaruh Benzyl Adenine (BA) Terhadap Pertumbuhan Eksplan Dua Kultivar Krisan Secara In Vitro. Skripsi. Institut Pertanian Bogor, Bogor.

Tilaar W, Rantung dan Tulung. 2015. Induksi Tunas Dari Nodul Krisan Kulo Dalam Media Murashige Dan Skoog Yang Diberi Sitokinin. Jurnal Eugenia. 21 (2).

Wahyudi, E., Ernita , Fathurrahman. 2013. Uji Konsentrasi kinetin dan NAA Terhadap Multiplikasi Embrio Aren Secara In Vitro. Jurnal Dinamika Pertanian. XXVIII (1).

Wattimena, G. A. 1988. Zat Pengatur Tumbuh Tanaman. Departemen Pendidikan dan Kebudayaan Direktorat Jenderal Pendidikan Tinggi Pusat Antar Universitas, Institut Pertanian Bogor, Bogor.

Wediyanto. 2007. Standart Operasional Prosedur Budidaya Krisan Potong. Departemen Pertanian, Jakarta. 